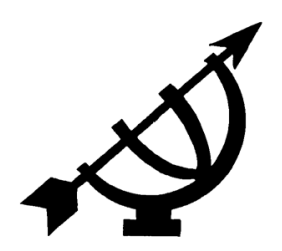

\title{
The Spirit and secularisation
}

\author{
D.T. Williams
}

Department of Historical and Contextual Theology

University of Fort Hare

ALICE

E-mail:dwilliams@ufh.ac.za

\begin{abstract}
The Spirit and secularisation

The existence of creation, especially of life, depends on the work of the third Person. In keeping with his nature as holy, the Spirit undergirds creation by providing separation and relatedness. This activity is, however, not of such a kind as to remove the measure of freedom that God gave through his selflimitation, and that is necessary for creation to occur. It is possible for individuals and society as a whole to ignore the Spirit, and for secularisation to occur. The action of the Spirit also underlies the new creation, which results in a distinctive society, the church, which is characterised by separation and relatedness. Through the church, the Spirit seeks to influence society as a whole by example without removing its freedom. To maintain the validity of this example, the Spirit also seeks to develop the church as a holy society, specifically counteracting the factors that produce secularisation in society.
\end{abstract}

\section{Opsomming}

\section{Die Gees en sekularisasie}

Die bestaan van die skepping, veral van lewe, hang van die werk van die derde Persoon af. Getrou aan sy heilige aard, onderskraag die Gees die skepping deur skeiding en verwantskap daar te stel. Hierdie werking is egter nie van so 'n aard dat die mate van vryheid, wat God deur sy selfbeperking gegee het, verwyder word nie, en dit is noodsaaklik dat skepping plaasvind. Dit is vir individue en die samelewing as geheel moontlik om die Gees te ignoreer sodat sekularisasie wel plaasvind. Die werking van die Gees lê ook ten grondslag van die nuwe skepping, wat uitloop op 'n eiesoortige gemeenskap, die kerk, wat deur skeiding en verwantskap gekenmerk word. Deur die kerk streef die Gees om die samelewing as geheel by 
wyse van voorbeeld te beïnvloed sonder om die vryheid daarvan weg te neem. Om die geldigheid van hierdie voorbeeld te handhaaf, streef die Gees om die kerk as 'n heilige gemeenskap te ontwikkel, terwyl dit spesifiek die faktore wat sekularisering in die samelewing veroorsaak, teenwerk.

\section{Introduction}

Even a slight acquaintance with the recent history of western society reveals that it has become increasingly secularised. In contrast to the situation in the Middle Ages where the influence of the church pervaded every aspect of society, the modern western world operates with almost no reference to it. This article can be considered against the background of two other articles by the same author, published in this journal. The first article (Williams, 2007), looked into the factors which contributed to the increasing secularisation, and related it to God's self-limitation in creation, giving a measure of freedom to humanity. The second article (Williams, 2008) dealt with the response of God to the sin that his self-limitation has permitted in sending his Son to enable salvation. This involved the Son's own self-limitation in incarnation and death (Phil. 2:7). Seeing the relationship of the first two Persons to the secularisation process naturally prompts an enquiry into the relationship to this by the third Person.

\section{The Spirit in creation}

Jürgen Moltmann entitles his major work on the Holy Spirit The Spirit of life, in the original German, Der Geist des Lebens. He does this from the fairly commonly held conviction that life is only possible, and is sustained by the immanent presence of God in everything (Moltmann, 1992:8). The belief is that if there is no continual outpouring of the Spirit, there can be no existence (eg. Hordern, 1984: 90). Elsewhere, Moltmann (1985:102), on the basis of Psalm 104: 29 , expresses the belief that the absence of God would mean the non-existence of the world. Nothing and nowhere can be closed to him. The psalmist takes comfort in the belief that God is even present to the dead (Ps. 139:7 ff.). "Whither shall I go from thy Spirit?" (Ps. 139:7). It is not a big step from this to a belief that every existence depends on the direct activity of God; Hebrews 1:3 can well be cited in this regard, "... upholding the universe by his word of power".

However, it might well then have been expected that the influence of God on human life would have been more effective than seems to 
have been the case, preventing the marginalisation of God in particularly western society, a process commonly referred to as secularisation. In this case, if the Spirit is indeed present in everything, the nature of his presence must be such that He does not compel awareness of God or conformity to his desires.

Certainly in a large part of the western church, if the Spirit is present, this presence seems ineffective. Even if, at least until comparatively recently, it was the normal practice for young people to be received into the church, either they were never Christians, and never received the Spirit, even in confirmation, or they received, but ignored his promptings, an attitude which is the essence of secularisation. This latter situation is paralleled in society as a whole, where the church is present, but ignored.

While the Spirit is understood to be involved in creation, especially of life and human life in particular, then in salvation, the "new creation", the nature of this is consistent with secularisation. The question then must be whether indeed the Spirit continues to be present so widely in creation and in the church, and then, if so, why his presence seems to be so ineffective.

\section{Secularisation inherent in creation}

In the context of his belief in the omnipresence of the Spirit, Moltmann (1985:86) is also well-known for his recognition that existence requires the self-limitation of God. He refers to the idea of the zimsum of God held by Isaac Luria, a sixteenth-century Jewish mystic of the Kabbalah (Richard, 1997:139), which is that God concentrates Himself, as in the shekinah. He contracts his omnipresence, giving space for another entity (Taylor, 1992:193). Harries (1991:2) cites the delightful old Jewish saying that "God picked up the skirts of his clothing to create a tiny space where he was not, in order that there might be a space where free creatures could live". This self-limitation is felt to be necessary for the very existence of anything other than God Himself. If God has distinguished Himself from the creation, it is not surprising that several have seen the modern western secular worldview as rooted in Christianity, and specifically in the Old Testament (Berger, 1969:113 ff.). The same feature can be true of life, where God withdraws more to enable increasing independence.

\section{Secularisation through grace}

If the process of secularisation is inherent in the act of creation, due to God separating Himself in order to give existence, and especially 
free action, it follows that secularisation is also likely to be inherent in the "new creation" (2 Cor. 5:17), by which God works to reconcile humanity to Himself. He seeks to do this without taking away the human freedom given in the first creation, but on the contrary, enhances it.

Paradoxically, the receipt of salvation by grace can also be seen to have a secularising result. Being assured of salvation, people often did not see the need for obedience to God, or even of acknowledging Him in this life. Even in the New Testament, Paul had to confront those who felt that the receipt of salvation by grace did not compel the adoption of a christian lifestyle (Rom. 6:1, 15). Indeed, where salvation by grace has been emphasised, this has been a recurring feature. Where conformity to the will of God is not deemed important, relating to Him is less valued, and at the same time those outside the church are naturally less inclined to respond to its appeal.

\section{Secularisation by incarnation}

Also paradoxically, is a further subtle danger lurking, namely that the welcomed realisation that faith must result in a changed life can well mean a concentration on this life, and the irrelevance of the future hope. This can well be a further impetus to secularisation.

At the same time, the taking of humanity by the second Person means that humanity is thereby dignified. Especially in modern theology, coinciding with the main period of secularisation, humanity is stressed, and the effect of faith in life is emphasised. Theology is done "from below", from an assumption of humanity, and not from unverifiable premises assumed in a practice "from above". It is naturally expressed in the "social gospel", and more recently in liberation theology, in largely social terms.

\section{The work of the Spirit in the creation}

Yet, even in the secularising effects of creation and new creation, the presence of God's Spirit can be affirmed. Existence requires two things, namely that things are distinguishable, and that they exist in a relationship to others. Existence does not just require relationship, but it also needs separation and distinctiveness. An object does not really exist unless it is distinguishable from others; it is therefore limited. Without those features there is chaos and non-existence. However, these two aspects can be related to the Holy Spirit, and it is therefore reasonable to see his action in every existence. On the 
one hand, the basic idea of holiness is separation or distinctiveness, but on the other, as Augustine realised, He has a function of bonding. Indeed, a fundamental aspect of the Genesis account of creation is separation, as between light and darkness, while at the same time $\mathrm{He}$ enhances relatedness.

Blocher (1984:69) cites Kline, who describes the rūah as "neither in heaven nor on earth, but between one and the other". The significance of this assertion is that the relationship produced by the Spirit is necessary, because of the differentiation produced in creation. For Beaucamp, the Spirit "'balances the principle of separation by being placed at the opposite pole'; if the Word brings about diversity, the Spirit unifies" (Blocher, 1984:70). The action of the Spirit is especially significant in the light of God's self-limitation, as this means an independence of the creation from God. There was a need to give a specific relationship between the two.

As life developed, there was greater action of the Spirit in clearer inter-relating and greater distinctiveness. An obvious example is in sexual reproduction, which depends on inherent distinctiveness from others of the same sex, from other potential mates, and from other forms of life. Reproduction is by relation.

These features appear in humanity, which is described in imago Dei (Gen. 1:27). Humanity is distinct from the rest of creation; an appreciation lost in secularisation (Taylor, 2007:90). This is most commonly understood in terms of dominion, which demands both relatedness, and also a distinction from what is dominated. Especially in Barth (1958:184 ff.), it is understood as meaning the distinction of plurality. It is no accident that Genesis 2 relates the origins of humanity to the Spirit. What may be especially noted here is that dominion demands plurality, as the power of humanity comes from people working together. If this is not appreciated, there is perversity, as an emphasis on dominion without an appreciation of relatedness results in oppression.

The Genesis account records a deliberate act of choice, made possible by God's self-limitation. It is significant that the fundamental sin was when the primal human couple responded to the temptation, "you will be like God" (Gen. 3:5), therefore from a loss of distinctiveness. This resulted, naturally, in a loss of relatedness, first from God, then from the environment and from other people. 


\section{The dual work of the Spirit}

The features of existence reflect, not surprisingly, the fundamental characteristics of God himself in Trinity, as three distinct, but interrelated Persons. It was an insight of Augustine that the Spirit bonds the Father and Son as the vinculum amoris, bond of love. It is the interplay in this relationship, known as perichōēsis, that enables the Persons to be equal, while remaining distinct. The interaction of perichōrēsis enables the full three-in-oneness of the Trinity (Barth, 1975:370). Moltmann (1981:175) says of the Persons of the Trinity that "in the perichoresis, the very thing that divides them becomes that which binds them together". Peters (1993:147) feels that "the concept of perichoresis holds together the dimensions of absoluteness and relatedness in the single divine life".

Suggesting an action of the Spirit as producing distinctiveness and relatedness in itself is not surprising, as it reflects the essential duality in the christian understanding of God and of the Spirit as theistic, thus both transcendent and immanent. A view of God which excludes either aspect is inadequate.

In fact, Moltmann reflects a dual aspect of the work of the Spirit, but interestingly does not relate this to the fact that God is both transcendent and immanent, but to the western view of the double procession of the Spirit from both Father and Son. He feels that this view has had the effect of stressing the procession from the Son at the expense of the procession from the Father; this has linked the work of the Spirit primarily to redemption. While he then argues that the Spirit must be in all creation as proceeding from the Creator (Moltmann, 1992:8), his affirmation of a double procession in fact results in the same essential duality; the Spirit is immanent in creation, but is also the giver of transcendent life through the Son. In any case, even leaving aside the complexities and ambiguities in the historical reasons for affirming the filioque, what must be affirmed is that the Spirit then relates to the Father, whose nature is to be hidden, transcendent. Attention must also be drawn to Moltmann's own view of a way of reconciling East and West by procession from the Father-of-the-Son (Moltmann, 1981:183). However, it is not then surprising that the secularisation inherent in creation, reflecting this transcendence, is balanced by a further work of the Spirit, rather reflecting his production of relatedness. 


\section{The nature of the action of the Spirit}

It is quite true that the existence of anything depends on separation and on relationship. Any object exists by distinction from others and by the interaction of the constituent elements, even down to the atomic level. It is quite true that these are consistent with the action of the Spirit, especially that He fundamentally generates relationship. Nevertheless, while this may indeed indicate an action of the Spirit in creation, it does not demand a continuing action. The Spirit can well be seen as initiating, but not sustaining.

More clearly, the action of the Spirit is absolutely essential for life (Gen. 2:7; Ez. 37:9 ff.), but again, this does not mean that life is dependent on the continual direct intervention of the Spirit. The nature of life is the interrelationship of the parts of the body; while this has to be initiated, it can be self-perpetuating (Williams, 2002: 273). The workings of an engine can provide a parallel, exhibiting some, although not all, of the features of a living being; once it has started, it runs by the interaction of the various components, taking in fuel and excreting its waste. Indeed, Frost (1971:13) compares the action of the Spirit to the starter and accelerator in a car. Once the engine fires, that action can stop, as the process is self-perpetuating. The very idea of "breathe" in the Genesis account (Gen. 2:7) implies a single event.

Blocher (1984:75) cites Bonhoeffer's view that a key aspect of life is the ability to create life itself. This means the ability to give an existence independent of the one giving it, an idea very much in keeping with Moltmann. Bonhoeffer also points out that life is dead unless it has freedom (Blocher, 1984:75); this is only possible if God enables it by curtailing Himself.

In this case, God has created the laws and framework for the universe, an action reflected in Hebrews 1:3. Things can only act within those laws, but because they exist, existence and life can proceed without God's specific involvement. This does not mean that $\mathrm{He}$ is absent, as in Deism, but that He does not need to act constantly for the world to proceed. He may well, of course, in his sovereignty, choose to involve Himself. Incidentally, this principle can be applied to creation itself, which may be understood as through evolution, but in terms of God's framework of law, an approach known as "theistic evolution". Another understanding, that of "intelligent design", also accepts evolution, but with God's occasional direct creative acts at key points, such as the emergence of life, it recognises that the existence of law without these is inadequate. An understanding 
which embraces all three aspects together is consistent both with the scientific facts and a christian affirmation (cf. Williams, 2010).

\section{The work of the Spirit in new creation}

The same features of the action of the Spirit pertain in the new creation. The heart of the christian gospel must be the incarnation of Christ, culminating in the cross, resurrection and ascension. The presence of the Spirit is absolutely essential for salvation, applying the work of Christ for forgiveness, and uniting the believer to Him for eternal life. Both aspects are essential; in both, the work of the Spirit applying the work of Christ is vital. Nobody can be a Christian without this. John 3:5 refers to the new birth by the Spirit, and Romans 8:9 is very explicit, "anyone who does not have the Spirit of God does not belong to him". We are the temple of the living God (2 Cor. 6:16). This twofold action of Son and Spirit can be seen to be inherent in the very nature of God's action. Irenaeus is noteworthy, among other things, for his teaching of the works of the Son and Spirit as the "two hands of God" (Adv Haer 5.16.2-3; cf. Williams, 2003), an expression that puts an emphasis on the complementary work of Son and Spirit. Although Moltmann (1992:9) is primarily thinking of cosmic renewal, he can affirm a further action: "the Spirit is present wherever Christ is present".

As in the original creation, the fundamental actions of the Spirit occur here. There is a separation produced between those who are saved and those who are not. An appreciation that salvation is fundamentally an act of grace must serve to heighten the awareness of the distinction between the Creator and the created. At the same time, this is the means by which people are able to be brought into relationship with God in Christ, and so reverse the separation from God that is a result of sin. The church, in receiving the fullness of the Spirit, experiences the overcoming of the distinction between God and people characteristic of the Old Testament.

Just as the action of the Spirit can be seen as essential in all existence, there is a universal action in salvation. Christ died for the sins of the entire world, making forgiveness universally available. However, unless there is a specific act of grace in the individual, relating him or her to God, thus giving eternal life, that salvation is incomplete. If salvation were simply by the incarnation, the unity of God with humanity, this would be an effective compulsion and so a negation of the purpose of God. The freedom given in creation is maintained. Indeed it is enhanced: salvation is liberative, giving freedom from the compulsion to sin. 
This salvation should be accompanied by a repentance and adoption of a christian lifestyle. However, while justification gives a relationship with God, it is static. It does not follow that a believer is thereby compelled to sanctification and so to affect society. There can well be relationship, but without interrelating, thus without effect. A phone connection can well be made, but without a conversation following. The engine can be assembled completely, but never started.

\section{Action through agents}

While it is possible to suggest that the Spirit is present in all creation, simply because of the nature of existence, and while his action in the new creation is essential to apply the work of Christ, these in themselves do not inherently act against secularisation. They reflect a relationship, but not its development. However, there is a further factor in the action of the Spirit; his separation and consecration of individuals to act for Him. In contrast to, or perhaps supplementing, the suggested presence of the Spirit in creation, a biblical understanding sees distinct actions of the Spirit in the Old Testament period. The Old Testament is clear that some individuals are particularly endued with the Spirit (Jud. 14:6; etc.). It was this that underpinned the distinct relation of Israel to God in covenant, the awareness of his will, and thus a sacral society. It was these specific interventions that avoided an otherwise natural drift towards secularisation. The existence of law without these was not adequate. God maintains his withdrawal from the world, his transcendence, by means of his action in the world by agents. These act against the secularising tendency of God's effective absence. However, these actions of the Spirit were only occasional, and limited to very few people.

The raising up of specific individuals in Israel, their consecration, reflects the nature of the Spirit as separating. However, this was done to lead the people into a full conformity with God, and was based on the complementary action of the Spirit in generating relation. It was not just a supposed presence of the Spirit in all of matter, or even in all of life, but on the earlier action of the establishment of the covenant, which was in itself arguably an action of the Spirit. Symbols such as fire are commonly associated with this. Two actions of the Spirit complement each other: on the one hand the establishment of covenant is an act of immanence, linking the entire community to God; on the other hand the designating of individuals, separating them for service, reflects transcendence. This action of the Spirit 
through agents continued in the church, where it has been necessary for definite teaching to be given, such as obedience as an act of gratitude for grace. Without the second work, the first, establishment of covenant, would seem to be insufficient. There needed to be a twofold action.

In the fullness of God's assumption of humanity, with its secularising implications, came the fullness of the Spirit. In the glorification of the Son, and a shift of emphasis to his continued presence in the church, the Spirit was sent (John 7:39). It is this that counteracts the secularising influence of the process of salvation. The Spirit gives a second work which is dynamic, based on the static relationship of justification of the first.

In contrast to the situation of the Old Testament, where the Spirit acted only occasionally, He came in fullness on the church at Pentecost after the ascension of Jesus. This means a further distinction: the Spirit is in the church in a way in which He is not present in the world. Jesus is emphatic that the world cannot receive Him (John 14:17). While He is present in creation and new creation, but in a static sense, $\mathrm{He}$ is now present dynamically. John 14:17 reflects a contrast between the Spirit being "with" the disciples, and the anticipation of his becoming "in" them. In the fullness of his presence $\mathrm{He}$ continues to act by generating distinction and relation.

\section{The Spirit as separating}

As holiness is fundamentally separation, the action of the Spirit in consecrating agents is consistent with this, therefore countering secularisation by distinctiveness. This essential delimitation in the work of God continued, but this was for the benefit of society and to give his direction. In his presence in the church, its distinction from the world is stressed, and in this way the world is affected. Separation is not a rejection of the world, but for the sake of the world. God desires all to be saved (1 Tim. 2:4). Any distinctiveness is then for the sake of an enhanced relationship. The prophets were called, separated and consecrated for the sake of Israel. The separation of Abraham was not even just for the sake of Israel, but for a wider relationship (Gen. 12:3). The presence of the Spirit in the church, while giving a separation from the world, is for the sake of its relationship to God.

Just as the Old Testament priesthood was separated from the rest of Israel, and consecrated in its service, so are the church ministers to the world. The church is separated as a kingdom of priests (1 Pet. 
2:5). The priesthood of all believers does not just reflect the truth that all Christians enjoy unmediated access to God, but its role in service to the world through its separation and consecration. There is no fundamental separation between clergy and laity, which can be secularising, but ministry is the task of the whole church. Several traditions, especially in the last century, have stressed the idea of "body ministry", reflecting the gifting of all for ministry to all.

The priesthood is a static relationship, due to an act of separation and consecration. It does not affect others directly. With all the associated aspects of the Old Testament cult, it highlighted the transcendent, the existence of holiness, and in this affected the rest of Israel. In the same way the priesthood, that is the church, displays holiness in contrast with the rest of society. It was this contrast that was effective in the early church. Even Julian the apostate had to concede, grudgingly, that the Christians even "feed our poor as well" (Hengel, 1974:45). Both Justin and Tertullian comment on the extent of voluntary giving in the church of their day (Hengel, 1974:67). What the Spirit does, is to emphasise a contrast between an effectively godless world and a church which lives through the Spirit. These things demand the separation that the Spirit gives to contrast with the world. The contrast is sharpened, and therefore produces the motivation to follow God.

The fundamental action of the Spirit is that of separation, and his action against secularisation involves the limitation of his presence to the church. By the example of the church, society is motivated to a transformation of its mind. This is the essence of sanctification (Phil. 2:5; Rom. 12:2), and counteracts the attitudes which are the essence of secularisation. The Spirit inspires the centring on God, the opposite of which results in his marginalisation.

Indeed, the recognition of a need for a christian lifestyle in the converted, but at the same time of the influence of a sinful world, led to separation from the world for the sake of sanctity. The height of this was of course monasticism, but it has occurred frequently in christian history - a notable modern example being the Amish. At first sight, just as social division can be a root of secularisation (Taylor, 2007:431), this might seem to be a further secularising influence, but by the visible difference and example to society, can well act against secularisation. The influence of the monasteries was beneficial to medieval society (Workman, 1927:153); "far more impressive than Benedictine austerities have been Benedictine services to mankind" (Hannah, 1924:84). The Reformation is commonly felt to have provided an impetus to secularisation (Williams, 2007:107 ff.); 
its destroying of the monasteries contributed to this by eliminating the influence of a separate christian society.

Obviously the church also gives a positive action in society in its interaction with it. For example, any acts of honesty are directly beneficial. Although this does produce some effect in society as a whole, the main effect is by heightening the contrast between church and society. As Taylor (2007:520) points out, the main loss to the church is not so much from definite atheism, but lack of commitment. A person does not really appreciate health until something goes wrong, but even more when it can be contrasted with a healthy person.

Thus the Spirit acts in society in a secondary way, because He is not received by the world, through his action in the church. Carson (1979:565), commenting on John 16:8, points out that the conviction of the world of sin, righteousness and judgement is not a direct action of the Spirit, but an action that happens through the church. He argues that the action of the Spirit is not upon the world as such, but on the church, the disciples, who are themselves convinced of the wrongness of the world.

\section{The action of the Spirit countering secularisation in the church}

The effectiveness of influence by example is obviously enhanced by increased holiness in the church. Even the direct action of the church in its evangelism demands that it presents a good example, as this gives proof of the truth of its words and evidence of the reality of its message. If the church is to be effective, it must show in its lifestyle the reality of God, and give evidence of the reality of its new life. This is particularly so in a postmodern environment, where secularisation has progressed to a great degree. Jones (2001:118 ff.) comments that a person in that situation will not respond to logical argument, but can only be won over by observing the quality of a transformed life, especially the expression of love in caring relationships.

In his fullness, the Spirit enables the sanctification of the church, which is then effective against secularisation in the society as a whole. The Spirit acts in consecration both in justification and then in the ongoing process of sanctification of those consecrated. The latter is God's answer to secularisation in society. Thus, as well as separation by the Spirit, comes his generation of increased relation. The church experienced the transcendence of the compartmentalis- 
ation in society that undergirds the secularisation process (Williams, 2007:105). An example of this is the overcoming of the distinctions in society, such as between slave and free (Philm. 16; Gal. 3:28), and especially between Jew and Gentile (Eph. 2:14).

Sanctification, however, is not complete; it is an ongoing process in which Christians are progressively conformed to God. At the same time there is a real danger that rather than the church influencing the world, the church itself shares in the secularisation of society (Williams, 2007:115), ignoring and marginalising the Spirit. Such "accommodation [must be] a disastrous option" (Williams, 2008:106). It must also be recognised that as sanctification is largely a process, the world can be encouraged to make even initial small steps in that direction.

The presence of the Spirit is given to the church so that obedience to God in the world is motivated, but without negation of essential freedom. That same freedom remains in the church and is even enhanced. Secularisation is a possibility because of the freedom of action given to people in the creation, and the presence of the Spirit in the church does not take this away. The Spirit urges, but does not compel; He has even been described as "shy" (Packer, 1992: 226). His action, as that of the other Persons, is self-limited. This means that the presence of the Spirit in the church does not guarantee his ongoing activity in producing sanctification. It is quite possible for Christians, and the church, to act, but without the Spirit - this can be ineffective. An example of this is in the Lord's supper where its effectiveness is not just by virtue of its performance, ex opere operato, but as Calvin appreciated (Inst. iv.15.6 quoted by Wendel, 1965:321), it is the Spirit who links a real believer to the risen Christ.

Nevertheless, the Spirit acts in the church to enhance its holiness. The Spirit reminds and brings to attention, usually through the work of consecrated individuals. He positively encourages and strengthens the church; it is appropriate that paraklētos is often translated as "comforter". These are actions of his immanence.

Of course, at the same time, it is quite possible, in their godgiven freedom, for people to act without God to generate a better, even a more moral world. Indeed, that must be the desire of Christians, and should even be motivated by the sight of life in the church. Nevertheless, such a world is still secularised insofar as it acts without reference to God. Christian desire must also be shown; not just the quality of a transformed lifestyle, but also the means by which such a lifestyle becomes achievable. Christian desire should not be just 
the proclamation of God's means of giving eternal life only after death, but also in the present. Often the church shares the condemnation of "holding the form of religion but denying the power of it” (2 Tim. 3:5).

In an earlier article (Williams, 2007:109 ff.), I noted the factors that are generally seen as underlying secularisation. Through relationship with Christ, the Spirit counters these. This happens primarily through the bonding and relationships in the church. Just as in the individual Christian, the action of the Spirit is clearly essential for the church. Augustine referred to Him as the anima ecclesiae, soul of the church (Heron, 1983:95). Just as the soul in a person may be understood as the interrelating of the various organs in the body, so the Spirit enables this in the church. "Without the support of a vigorous community, it is not likely that the faith of most individuals would prosper" (Williams, 2008:104). Whereas urbanisation and associated mobility underlie the growth of individualism, the relationships in the church should compensate for this. These factors were of course associated with industrialisation, itself secularising due to its adoption of the practice of division in labour, which although efficient, does separate. However, division in labour in itself need not be a secularising factor, since the Spirit, by his gifting, gives distinct roles in the church. What is distinctive in the church is the clear interrelating of these roles (1 Cor. 12:4 ff.).

These factors of course may be seen as a direct result of the change in mental set in the Enlightenment, an attitude basically characterised as rationalist. The effect of this is immediately countered by any evidence of the direct working of the Spirit as in a miracle. At the same time, a major effect of the Spirit in the church is that of sanctification, which is primarily the transformation of the mind (Rom. 12:2; Phil. 2:5, etc.). This transformation counters the negative effects of the free market worldview spawned by the Enlightenment, for the Spirit produces the opposite to capitalist self-seeking in his development of humility. It is this which I suggested is the key to the countering of secularisation: by imitation of the example of the self-limitation of Christ Himself (Williams, 2008:111). The Enlightenment attitude of human autonomy, which naturally marginalises the divine, must be challenged by an awareness of the divine in the presence of the Spirit. It is noteworthy, albeit a reprimand to much of the modern church, that Paul could treat the presence of the Spirit in the church as so evident that he can argue from it (Gal. 3:2). How often the modern church has to attempt to prove that the Spirit is in fact a reality! 


\section{The provision of a complementary transcendence}

With the development of secularisation, it is understandable that the twentieth century witnessed a major movement that emphasised the transcendent, a movement that proved to be extremely significant. It is estimated that about a quarter of Christians now identify with the Pentecostal churches or the movements that emerged from it. These churches and movements stress the intervention of the Holy Spirit directly into peoples' lives and the practice of the gifts which are believed to be given by Him. This is emphatically not mundane; the manifestation of the Spirit is through grace, and his gifts are divine, not human abilities.

The Pentecostal movement traces its roots through the holiness groups, especially in America, and so to Wesley. The emphasis on a "second blessing" has clear affinities to the Aldersgate experience in 1738 , in which Wesley felt his heart "strangely warmed". Wesley is noteworthy for his teaching of an experience of "entire sanctification". Even if the term and understanding of this is debatable, the essence is of a second work of grace by the Holy Spirit resulting in sanctification. It is only when He comes into fullness that there is an effect on behaviour and the transformation of the mind. Indeed, the early Pentecostals interpreted the "second blessing" in terms of sanctification - it was only later seen more in terms of the receipt of power. What is also clear is that the result of the experience in the Wesleyan revival was dramatically effective in England, significantly in a time of rapid secularisation. Effectively a work of the Spirit countered secularisation, but this was not associated with the action of the Spirit in salvation or regeneration, but with a subsequent experience of filling with the Spirit.

Indeed, if the action of the Spirit in the creation of life was a single enlivening action, and if his action in justification was a single action in the establishment of the bond to Christ, it is really not surprising that the further action in enlivening what had been established, in sanctification, was not limited to a process, but could be in further events. These are emphatically all acts of grace, of God intervening, actions of transcendence to complement his continued immanent presence.

There is, incidentally, a paradox here in that traditions which have emphasised the grace of God in justification have tended to stress human action in sanctification, albeit empowered by the Spirit. Those that acknowledge the human response in justification, such as the Wesleyan and those emerging from it, have nevertheless 
been more open to recognising specific events of grace in sanctification.

\section{Conclusion}

Secularisation is a marginalisation of religion in society. Its opposite is a society centred on God, which reflects his very nature. It is this which is facilitated by the Spirit - in this He produces a society which reflects the very nature of the Trinity.

The Spirit produces a separated lifestyle, which is holy and noticeable, and reflects the transcendence of the Father. The Spirit empowers fulfilment of the ideal of the imitation of Christ. As Jesus himself, the church speaks prophetically to society. The Spirit generates his own nature in the church. Therefore, in addition to separation, which reflects his transcendence, He produces good interrelating (1 Cor. 12:4 ff.), reflecting immanence, and wholeness. He gives his fruit (Gal. 5:22), such as joy and peace; these are qualities which are desirable by society as a whole.

It was again Augustine who, however strangely, affirmed the goodness of sin. However, this was immediately qualified by the proviso that it had to been redeemed. It was in his goodness that God gave a measure of freedom to people, resulting in what was perhaps the inevitability of sin. However, in his goodness, He dealt with this not by just reversing his creation, or by denying freedom, but by providing the means, in the Spirit, for a holy society to emerge. May we, in our freedom, respond correctly!

\section{List of references}

BARTH, K. 1958. Church dogmatics. Vol. 3(1): The doctrine of creation. Edinburgh: Clark.

BARTH, K. 1975. Church dogmatics. Vol. 1(1): The doctrine of the Word of God. 2nd ed. Edinburgh: Clark.

BERGER, P.L. 1969. The sacred canopy: elements of a sociological theory of religion. New York: Doubleday.

BLOCHER, H. 1984. In the beginning: the opening chapters of Genesis. Downers Grove: InterVarsity.

CARSON, D.A. 1979. The function of the paraclete in John 16:7-11. Journal of biblical literature, 98(4):547-566.

FROST, R.C. 1971. Aglow with the Spirit. Rev. ed. Plainfield: Logos International.

HANNAH, I.C. 1924. Christian monasticism: a great force in history. London: Allen \& Unwin. 
HARRIES, R. 1991. Human rights in theological perspective. (In Blackburn, R. \& Taylor, J. Human rights for the 1990s: legal, political and ethical issues. London: Mansell. p. 1-13.)

HENGEL, M. 1974. Property and riches in the early church. Philadelphia: Fortress.

HERON, A.I.C. 1983. The Holy Spirit. Philadelphia: Westminster.

HORDERN, W. 1984. The Holy Spirit and the theology of the cross. (In Bruner, F.D. \& Hordern, W., eds. The Holy Spirit - shy member of the Trinity. Minneapolis: Augsburg. p. 87-108.)

JONES, T. 2001. Postmodern youth ministry: exploring cultural shift, creating holistic connections, cultivating authentic community. Grand Rapids: Zondervan.

MOLTMANN, J. 1981. The Trinity and the kingdom of God: the doctrine of God. London: SCM.

MOLTMANN, J. 1985. God in creation: an ecological doctrine of creation. London: SCM. (The Gifford Lectures 1984-1985.)

MOLTMANN, J. 1992. The spirit of life: a universal affirmation. Minneapolis: Fortress.

PACKER, J.I. 1992. Rediscovering holiness. Ann Arbor: Vine.

PETERS, T. 1993. God as Trinity: relationality and temporality in divine life. Louisville: Westminster John Knox.

RICHARD, L. 1997. Christ: the self-emptying of God. Mahwah: Paulist.

TAYLOR, C. 2007. A secular age. Cambridge: Belknap Press of Harvard University Press.

TAYLOR, J.V. 1992. The Christlike God. London: SCM.

WENDEL, F. 1965. Calvin: the origins and development of his religious thought. London: Collins (Fontana).

WILLIAMS, D.T. 2002. What is life? Koers, 67(3):271-282.

WILLIAMS, D.T. 2003. The "two hands of God": imaging the Trinity. Lincoln: iUniverse.

WILLIAMS, D.T. 2007. Secularisation from kenosis. Koers, 72(1):101-118.

WILLIAMS, D.T. 2008. A kenotic response to secularity. Koers, 73(1):101-119.

WILLIAMS, D.T. 2010. Evolution through kenōsis. Expository times, 121(8):390394.

WORKMAN, H.B. 1927. The evolution of the monastic ideal: from the earliest times to the coming of the friars - a second chapter in the history of christian renunciation. 2nd ed. London: Epworth.

\section{Key concepts:}

holiness as relatedness

holiness as separation

Holy Spirit

secularisation

self-limitation
Kernbegrippe:

Heilige Gees

heiligheid as skeiding

heiligheid as verwantskap

sekularisasie

selfbeperking 
